\title{
GAMBARAN SINDROMA PREMENSTRUASI DENGAN OBESITAS MAHASISWI FAKULTAS KEDOKTERAN UNIVERSITAS SAM RATULANGI
}

\author{
${ }^{1}$ Tiara Faradita Rahim \\ ${ }^{2}$ Hermie M. M. Tendean \\ ${ }^{2}$ Erna Suparman \\ ${ }^{1}$ Kandidat Skripsi Fakultas Kedokteran Universitas Sam Ratulangi Manado \\ ${ }^{2}$ Bagian Obstetri dan Ginekologi RSUP Prof.Dr.R.D. Kandou Manado \\ Email : ttiarafara@yahoo.com
}

\begin{abstract}
Premenstrual syndrome is a set of symptoms associated with the menstrual cycle. Usually appear one to two weeks before the menstrual period and disappeared after the start of menstruation. One of the premenstrual syndrome's risk factor is the body mass index. The prevalence of premenstrual syndrome in Virginia was 10,3\%. Obese women (body mass index $\geq 30$ ) had nearly a three fold increased risk for premenstrual syndrome than non-obese women. The purpose of this study was to know the description of premenstrual syndrome with obesity in female students of Medical Faculty Sam Ratulangi University. Method used a descriptive with cross sectional approach in 43 female students in Medical Faculty of Sam Ratulangi University that qualify. Based on the research in 43 female students of Medical Faculty Sam Ratulangi University, showed that the most distribution of respondents age was 20 - 22 years old (72,1\%), the most of obesity category is obesity type I with BMI $30-34,9$ $\mathrm{kg} / \mathrm{m}^{2}(95,3 \%)$, and mostly respondents have a premenstrual syndrome with predominant types of symptom was affective symptom.
\end{abstract}

Keyword: premenstrual syndrome, obesity

\begin{abstract}
Abstrak: Sindroma premenstruasi merupakan sekumpulan gejala yang muncul terkait dengan siklus menstruasi. Biasanya muncul satu sampai dua minggu sebelum periode menstruasi dan menghilang setelah mulainya menstruasi. Salah satu faktor risiko sindroma premenstruasi adalah indeks massa tubuh. Prevalensi sindroma premenstruasi di Virginia pada $10,3 \%$. Perempuan obesitas (indeks massa tubuh $\geq 30$ ) mempunyai risiko mengalami sindroma premenstruasi tiga kali lebih besar dibanding perempuan non obesitas. Tujuan penelitian ini untuk mengetahui gambaran sindroma premenstruasi dengan obesitas mahasiswi Fakultas Kedokteran Universitas Sam Ratulangi. Metode yang digunakan bersifat deskriptif dengan pendekatan cross sectional pada 43 mahasiswi Fakultas Kedokteran Universitas Sam Ratulangi yang memenuhi syarat. Berdasarkan penelitian yang dilakukan pada 43 mahasiswi Fakultas Kedokteran Universitas Sam Ratulangi, didapatkan distribusi usia responden terbanyak antara 20 - 22 tahun (72,1\%), kategori obesitas terbanyak adalah obesitas I dengan IMT berkisar antara $30-34,9 \mathrm{~kg} / \mathrm{m}^{2}$ (95,3\%), dan sebagian besar responden mengalami sindroma premenstruasi $(81,4 \%)$ dengan gejala yang paling dominan muncul adalah gejala afektif.
\end{abstract}

Kata kunci: sindroma premenstruasi, obesitas 
Sindroma premenstruasi atau premenstrual syndrome (PMS) merupakan sekumpulan gejala yang muncul terkait dengan siklus menstruasi. Biasanya muncul satu sampai dua minggu sebelum periode menstruasi dan menghilang setelah mulainya menstruasi. Sindroma ini bisa muncul pada perempuan usia reproduksi. Sindroma premenstruasi diduga terjadi karena perubahan hormonal selama siklus menstruasi. ${ }^{1}$

Sindroma premenstruasi ditandai dengan sederet gejala psikologi yang diikuti gejala fisik atau tanpa gejala fisik. Dr.William Vayda yang dikutip dalam buku Mood Foods membedakannya atas dua gejala umum, yakni gejala fisik meliputi perut kembung, sakit kepala, berat badan cenderung naik, pembengkakan dan pengerasan payudara, otot terasa lemas, dan rasa sakit disekujur tubuh dan gejala psikologi meliputi mudah tersinggung, gugup, gelisah, agresif, pemarah, sulit mengingat, tidak dapat berpikir jernih, mudah panik, kebingungan. ${ }^{2}$ Perempuan yang mengalami satu gejala menjelang haid selama tiga bulan berturut - turut dikatakan sedang mengalami PMS. $^{3}$ Diperkirakan 85 - 97\% perempuan mengalami gejala psikologis dan gejala fisik akibat sindroma premenstruasi. ${ }^{4}$

Berdasarkan penelitian yang dilakukan terhadap mahasiswi kedokteran di Purwokerto menunjukkan $53,3 \%$ memiliki sindroma premenstruasi, sedangkan 46,7 \% lainnya tidak memiliki sindroma premenstruasi. ${ }^{5}$ Berbagai faktor gaya hidup menjadikan gejala - gejala dari PMS ini semakin buruk, salah satunya obesitas. Namun awal kejadian, durasi dan gejalanya bervariasi pada setiap perempuan. $^{6,7}$
Prevalensi sindrom premenstruasi di Virginia pada $10,3 \%$ perempuan obesitas (indeks massa tubuh $\geq 30$ ) mempunyai risiko mengalami sindroma premenstruasi tiga kali lebih besar dibanding perempuan non obesitas. Dari data ini menunjukkan bahwa obesitas dapat menjadi faktor risiko terjadinya sindroma premenstruasi, namun ada beberapa penelitian yang menyimpulkan hasil yang berbeda. ${ }^{8}$ Beberapa teori menerangkan mengapa perempuan obesitas cenderung lebih banyak mengalami PMS meskipun penyebabnya belum diketahui secara pasti. Diduga hormon estrogen, prolaktin, dan aldosteron menjadi penyebab timbulnya sindroma premenstruasi karena jenis hormon ini menyebabkan terjadinya retensi cairan, sehingga terjadi penumpukan cairan di sel - sel tubuh terutama di kaki, otak, dan payudara. Biasanya perempuan mengeluh payudara sakit, kaki terasa berat, dan sakit kepala yang berlebihan. $^{9}$

Hubungan antara indeks massa tubuh dengan sindroma premenstruasi adalah melalui kerja hormon insulin. Kadar insulin di dalam tubuh berbanding lurus dengan presentase lemak di dalam tubuh. Peningkatan presentase di dalam tubuh menimbulkan perubahan pada sensitivitas dan sekresi insulin. Pada orang yang obesitas akan terjadi peningkatan kadar glukosa darah secara langsung. Peningkatan kadar glukosa darah akan berakibat terjadi glukoneogenesis. Hal ini akan mempengaruhi kadar insulin yang terus meningkat, yang disebut hiperinsulinemia. Selain itu insulin secara langsung dapat menurunkan sexhormone binding globulin (SHBG) pada perempuan obesitas. SHBG bekerja berlawanan dengan insulin yaitu menekan produksi androgen. Sedangkan insulin bekerja pada proses 
steroidogenesis untuk merangsang sel teka untuk memproduksi androgen. Tingginya kadar insulin akan menekan produksi SHBG, dan akhirnya terjadi hiperandrogen. ${ }^{10}$

Penelitian lain mengatakan hiperestrogenisme pada perempuan yang mengalami obesitas disebabkan peningkatan persentase lemak di dalam tubuh. Lemak terutama kolesterol merupakan bahan dasar pembentukan estrogen. Dengan demikian, semakin banyak persentase jaringan lemak dalam tubuh, semakin banyak pula estrogen yang terbentuk yang kemudian dapat menganggu keseimbangan hormon di dalam tubuh sehingga menyebabkan seorang perempuan beresiko mengalami sindrom premenstruasi. $^{11}$

Teori lain menyatakan ada banyak hal yang dapat mempengaruhi siklus menstruasi diantaranya status gizi, pola makan, aktifitas olahraga, dan lain lain. Indeks massa tubuh ditentukan oleh berat badan dan tinggi badan. Berat badan sangat mempengaruhi status gizi dalam kaitannya terhadap siklus menstruasi. Hal ini disebabkan oleh adanya adypocyte-derived hormone leptin yang berasal dari lemak tubuh yang diduga dapat mempengaruhi siklus menstruasi. ${ }^{12}$

Berdasarkan uraian di atas, penulis memperoleh gambaran bahwa obesitas merupakan salah satu faktor risiko terjadinya sindroma premenstruasi sehingga penulis tertarik untuk melakukan penelitian mengenai gambaran sindroma premenstruasi dengan obesitas di Fakultas Kedokteran Universitas Sam Ratulangi Manado.

\section{Tanda dan gejala sindroma premenstruasi $^{13}$}

\begin{tabular}{|c|l|}
\hline \multicolumn{1}{|c|}{ Gejala Fisik } & \multicolumn{1}{c|}{ Gejala Emosional } \\
\hline Perut kembung & Suka marah \\
\hline
\end{tabular}

\begin{tabular}{|c|c|}
\hline Nyeri payudara & Irritabilitas \\
\hline Sakit kepala & Suka menangis \\
\hline $\begin{array}{l}\text { Kejang atau } \\
\text { bengkak pada kaki }\end{array}$ & Cemas \\
\hline Nyeri panggul & Depresi \\
\hline Hilang koordinasi & $\begin{array}{l}\text { Sifat agresif atau } \\
\text { pemberontakan }\end{array}$ \\
\hline $\begin{array}{l}\text { Nafsu makan } \\
\text { bertambah }\end{array}$ & Pelupa \\
\hline Hidung tersumbat & Sulit tidur \\
\hline Tumbuh jerawat & Paranoid \\
\hline Sakit pinggul & $\begin{array}{l}\text { Perubahan } \\
\text { dorongan seksual }\end{array}$ \\
\hline Suka mengemil & $\begin{array}{l}\text { Konsentrasi } \\
\text { berkurang }\end{array}$ \\
\hline Palpitasi & Merasa tidak aman \\
\hline $\begin{array}{l}\text { Peka suara atau } \\
\text { cahaya }\end{array}$ & Pikiran bunuh diri \\
\hline $\begin{array}{l}\text { Rasa gatal pada } \\
\text { kulit }\end{array}$ & $\begin{array}{l}\text { Keinginan } \\
\text { menyendiri }\end{array}$ \\
\hline Kepanasan & Perasaan bersalah \\
\hline Kelemahan & \\
\hline
\end{tabular}

\section{Kriteria diagnostik sindroma premenstruasi}

American College of Obstetricians and Gynecologists (ACOG) telah mengembangkan kriteria diagnostik berikut untuk diagnosis sindroma premenstruasi. $^{14}$

Minimal mengalami satu dari masing - masing gejala afektif dan somatik berikut selama 5 hari sebelum menstruasi. Gejala harus muncul dalam tiga siklus menstruasi berturut - turut :

Afektif: depresi, mudah marah, sensitif, cemas, bingung, menarik diri dari 
sosial. Somatik: nyeri payudara, perut kembung, sakit kepala, pembengkakan ekstremitas. Gejala juga harus memenuhi kriteria sebagai berikut :

- Gejala menghilang dalam waktu 4 hari dari onset menstruasi

- Tidak sedang melakukan terapi farmakologis, konsumsi hormon, atau penggunaan narkoba atau alkohol pada saat bersamaan

- Derajat keluhan - keluhan cukup berat yang mempengaruhi kemampuan sosial dan ekonomi

\section{Cara mengatasi premenstruasi $^{3}$}

- Minum minuman hangat

- Minum air putih secukupnya setiap hari

- Mandi dengan air hangat

- Istirahat yang cukup

- Tidur dengan baik pada malam hari

- Berolahraga secara teratur

- Melakukan aroma terapi

- Melakukan pemijatan

- Mendengarkan musik

- Diet rendah lemak, garam dan gula, tetapi tinggi protein

- Memperbanyak konsumsi makanan yang mengandung serat

- Meminum obat pereda rasa nyeri dengan resep dokter

\section{METODE PENELITIAN}

Penelitian ini bersifat deskriptif dengan pendekatan cross sectional pada 43 mahasiswi Fakultas Kedokteran Universitas Sam Ratulangi yang memenuhi syarat inklusi dan eksklusi.

\section{HASIL DAN PEMBAHASAN}

Dalam penelitian yang telah dilakukan pada November - Desember
2015 di Fakultas Kedokteran Universitas Sam Ratulangi ditemukan sebanyak 80 responden berpatisipasi dalam penelitian ini dan didapatkan sebanyak 43 orang memenuhi kriteria inklusi dan eksklusi. Maka didapatkan hasil penelitian dengan analisa mencakup karakteristik berdasarkan subyek penelitian yang dirangkum dalam bentuk tabel.

Tabel IV.1 Karakteristik sampel berdasarkan usia, obesitas dan sindroma premenstruasi

\begin{tabular}{lcc}
\hline \multicolumn{1}{c}{ Karakteristik } & $\mathrm{n}$ & $\%$ \\
\hline Usia (tahun) & & \\
$\quad 17-19$ & 12 & 27,9 \\
$20-22$ & 31 & 72,1 \\
$\quad$ Total & 43 & $100 \%$ \\
\hline Obesitas & & \\
$\quad$ I $(30-34,9$ & 41 & 95,3 \\
kg/m $\left.{ }^{2}\right)$ & & \\
II $(35-39,9$ & 2 & 4,7 \\
kg/m $\left.{ }^{2}\right)$ & & \\
Total & 43 & $100 \%$ \\
\hline Sindroma & & \\
Premenstruasi & & \\
$\quad$ Ada & 35 & 81,4 \\
$\quad$ Tidak ada & 8 & 18,6 \\
$\quad$ Total & 43 & $100 \%$ \\
\hline
\end{tabular}

Pada tabel IV.1 menunjukan karakteristik berdasarkan usia sampel yang dilakukan pada 43 mahasiswi sebanyak 12 orang (27,9\%) yang berusia antara $17-19$ tahun. Sedangkan pada batasan usia antara 20 - 22 tahun terdapat 31 orang (72,1\%).

Karakteristik berdasarkan kategori obesitas didapatkan kategori obesitas terbanyak adalah obesitas I dengan IMT antara $30-34,9 \mathrm{~kg} / \mathrm{m}^{2}$ yaitu berjumlah 41 orang (95,3\%). Kemudian hanya 2 orang $(4,7 \%)$ dari sampel yang termasuk dalam kategori obesitas II dengan IMT berkisar 35 $39,9 \mathrm{~kg} / \mathrm{m}^{2}$. Prevalensi obesitas menurut Riset Kesehatan Dasar (Riskesdas) 
2013 meningkat jika dibandingkan dengan Riskesdas 2010. Angka pada wanita persentasenya dari $26 \%$ menjadi 35\%. Hasil Riset Kesehatan Dasar (Riskesdas) Indonesia pada tahun 2010 yang dikeluarkan oleh Kementerian Kesehatan menyatakan prevalensi obesitas pada perempuan tertinggi berada di daerah Sulawesi Utara, Kepulauan Bangka Belitung, dan Gorontalo. Dimana daerah Sulawesi Utara memiliki prevalensi obesitas sekitar $29,5 \% .^{15}$

\section{Tabel IV.2 Distribusi sampel sindroma premenstruasi}

\begin{tabular}{|c|c|c|c|c|}
\hline \multirow{3}{*}{ Karakteristik } & \multicolumn{4}{|c|}{ Sindroma premenstruasi } \\
\hline & \multicolumn{2}{|c|}{ Ada } & \multicolumn{2}{|c|}{ Tidak ada } \\
\hline & $\mathrm{n}$ & $\%$ & $\mathrm{n}$ & $\%$ \\
\hline \multicolumn{5}{|l|}{ Usia (tahun) } \\
\hline $17-19$ & 9 & 20,9 & 3 & 7 \\
\hline $20-22$ & 26 & 60,5 & 5 & 11,6 \\
\hline \multicolumn{5}{|l|}{ Obesitas } \\
\hline $\begin{array}{l}\text { I }(30-34,9 \\
\left.\mathrm{kg} / \mathrm{m}^{2}\right)\end{array}$ & 33 & 76,7 & 8 & 18,6 \\
\hline $\begin{array}{l}\text { II }(35-39,9 \\
\left.\mathrm{kg} / \mathrm{m}^{2}\right)\end{array}$ & 2 & 4,7 & 0 & 0 \\
\hline
\end{tabular}

Hasil penelitian pada tabel IV.2 menunjukan distribusi sampel berdasarkan ada dan tidak ada sindroma premenstruasi menurut usia dan kategori obesitas didapatkan hasil yang mengalami sindroma premenstruasi menurut usia antara 17-19 tahun berjumlah 9 orang (20,9\%), usia 20 22 tahun berjumlah 26 orang $(60,5 \%)$ sedangkan berdasarkan kategori obesitas I berjumlah 33 orang $(76,7 \%)$ dan obesitas II berjumlah 2 orang $(4,7 \%)$.

Penelitian lain menyatakan faktor risiko sindroma premenstruasi tidak konsisten dan kontradiktif. Faktor risiko lain termasuk nuliparitas, usia menarche dini, indeks massa tubuh tinggi, konsumsi alkohol berlebihan, konsumsi banyak kafein dan tingkat stress yang tinggi. Beberapa remaja perempuan mengalami sindroma premenstruasi dan tingkat keparahan yang sama dengan perempuan lebih tua. ${ }^{16}$

Mekanisme hormonal dan neurotransmiter yang menjadi penyebab terjadinya sindroma premenstruasi melibatkan beberapa hormon seperti estrogen, progesteron, leptin, serotonin dan neurotransmiter GABA. Hipotalamus sebagai pusat dari pengaturan aktivitas tubuh termasuk dalam mengatur emosi dan perilaku. Estrogen dan progesteron telah terbukti mampu memodulasi neurotransmiter pada beberapa tempat di jalur serotonin, yang berperan sebagai salah satu agen penyeimbang afek di otak, menimbulkan efek depresi, kemarahan dan agresivitas, iritabiltas, perasaan lemah, kehilangan kontrol diri, serta peningkatan keinginan kuat mengonsumsi karbohidrat. ${ }^{17}$ Hasil penelitian lain mendapatkan gejala afektif ditemukan pada seluruh sampel yaitu 54 orang atau sekitar $100 \%{ }^{18}$

Beberapa studi telah menunjukkan bahwa hampir semua individu obesitas mengalami peningkatan kadar leptin, mungkin karena peningkatan ekspresi gen lep dan sebagian karena produksi yang lebih besar dari sel - sel lemak. Leptin dikeluarkan ke dalam sistem sirkulasi oleh jaringan adiposa. Serum dan plasma leptin tertinggi terdapat pada orang yang memiliki indeks massa tubuh tertinggi dan total persen lemak tubuh yang dimiliki. Hormon leptin juga mengatur reproduksi dan emosi sehingga berkaitan dengan terjadinya sindroma premenstruasi. ${ }^{11}$

\section{SIMPULAN}

\section{Kesimpulan}

Pada penelitian ini disimpulkan bahwa dari 80 orang populasi, didapatkan 43 orang memenuhi kriteria 
inklusi dan ekslusi dengan kategori obesitas terbanyak adalah obesitas I (IMT 30 - 34,9 kg/m²) dan sebagian besar sampel yaitu berjumlah 35 $(81,4 \%)$ orang mengalami sindroma premenstruasi dengan gejala yang paling dominan muncul adalah gejala afektif.

\section{Saran}

- Diharapkan kepada pembaca perlu adanya pemantauan kesehatan wanita melalui pemeriksaan diri sendiri untuk mengenali sindroma premenstruasi sehingga dapat mengetahui cara mengatasi gejala dengan aman dan tepat.

- Dapat meningkatkan motivasi dan kesadaran dalam mengatur gaya hidup sehat

- Untuk peneliti selanjutnya diharapkan dapat meneliti tentang perbedaan antara sindroma premenstruasi pada obesitas dan non obesitas.

\section{DAFTAR PUSTAKA}

1. Sari W, Indrawati L, Harjanto BD. Panduan lengkap kesehatan wanita. Cetakan I. Jakarta: Penebar Plus ${ }^{+}$; 2012. 87

2. Apriadji WH. Good mood food. Jakarta: Gramedia pustaka utama.2011.

3. Laila NN. Buku pintar menstruasi. Cetakan I. Jogjakarta: Buku Biru; 2011. 28.

4. Kasgari KA, Shahhosseini Z, Danesh M. Assessment of starch dietary regimen regarding premenstrual syndrome among high school students in Sari during 2007. J Mazandaran Univ Med. Sci, 2007; (18) 19-27.
5. Retissu R, Sanusi S, Muhaimin A, Rujito L. Hubungan indeks massa tubuh dengan sindroma premenstruasi. Fakultas kedokteran dan ilmu-ilmu kesehatan Universitas Jenderal Soedirman. Purwokerto: 2010.

6. Anthony, Ian. Sindroma prahaid, wanita dan nutrisi health media nutrition series; 2008.

7. Mc Kinley Health Center University of Illinoisat Urbana Champaign. Nutrition and premenstrual syndrome. 2008.

8. Masho SW, Adera T. Paul. Obesity as a risk factor for menstrual syndrome. Journal of Psychosomatic Obsgyn. 2005.

9. Baziad MA. Endrokiologi ginekologi. Media Aesculapius FK UI. Jakarta: 2008; 87.

10. Speroff, Leon MA, Frizt. Regulation of the menstrual cycle. Dalam: Clinical Gynecology an Endocrinology and Infertility, Edisi ke-7. New York: Lippincott Williams and Wilkins; 2005.

11. Price SAP, Lorr MC. Gangguan sistem reproduksi perempuan. Jakarta: Penerbit Buku Kedokteran. 2006; 198-202.

12. Edward. Mean age of menarche in trinidad and its's relationship to body mass index, Ethinicity and mothers age of menarche. Anatomy Unit, Faculty of Medical Sciences University of West Indies. Online Journal of Biological Sciences. 2007. 7 (2): 66-71.

13. Rayburn. Obstetri dan Ginekologi. Jakarta: Widya Medika. 2012. 
14. American College of Obstetricians and Gynecologists. Premesntrual syndrome. ACOG Practice Bulletin No.15. Washington, DC: American College of Obstetricians and Gynecologists. 2001.

15. Chandra DA. Prevalensi obesitas pada remaja sma ypkm di kota manado [skripsi]. Universitas Sam Ratulangi Manado; 2014.

16. Freeman EW. Premenstrual syndromes. Global Library of women’s medicine. 2011.

17. Suparman E, Sentosa IR. Premenstrual syndrome. Jakarta: EGC. 2011; 30-1.

18. Bungasari SA. Gambaran sindrom prahaid pada remaja [skripsi]. Universitas Sam Ratulangi Manado. 2015. 